\title{
EFEKTIVITAS PENGGUNAAN METODE PENDIDIK TEMAN SEBAYA DALAM MENINGKATKAN PENGETAHUAN PENCEGAHAN KOMPLIKASI KAKI DIABETES DI PUSKESMAS BANGUNTAPAN 3 BANTUL
}

\author{
Riza Yulina Amry
}

Dosen STIKES Surya Global Yogyakarta

Jl. Ringroad Selatan Blado Potorono Banguntapan Bantul

E-mail : rizayulina@gmail.com

\begin{abstract}
ABSTRAK
Latar Belakang : Diabetic foot merupakan komplikasi yang biasa dialami oleh penderita diabetes melitus. Pengetahuan tentang komplikasi kaki diabetic diperlukan untuk melakukan perawatan diri dengan benar. Tujuan : menganalisis efektivitas pendidikan kesehatan metode pendidik teman sebaya terhadap peningkatan pengetahuan pencegahan komplikasi kaki diabetes. Metode : Quasi experimental dengan pre-post test control group design digunakan dalam penelitian ini. Intervensi pendidik teman sebaya digunakan dalam penelitian ini seluruh pasien Diabetes mellitus tipe 2 di Puskesmas Banguntapan 3 Bantul sebanyak 30 pasien. Pengambilan sampel menggunakan total sampling, responden terbagi 2 (15 intervensi dan 15 kontrol). Instrumen penelitian kuesioner pengetahuan tentang pencegahan komplikasi kaki diabetic yang diberikan sebelum dan sesudah intervensi, dianalisis dengan uji paired t-test. Hasil : Pretest pada kelompok control dalam kategori cukup $(73,3 \%)$ dan kelompok intervensi $(66,7 \%)$. Hasil postest kelompok control dengan kategori cukup $(66,7 \%)$ dan adanya peningkatan pada kelompok intervensi $(67,7 \%)$. Hasil analisa bivariate menunjukkan adanya pengaruh antara kelompok kontrol dan eksperimen terhadap pengetahuan perawatan kaki pada penderita dibetes dengan menggunakan pendidikan kesehatan metode teman sebaya dengan nilai p-value 0,006. Kesimpulan : metode pendidik teman sebaya terbukti efektif meningkatkan pengetahuan pencegahan komplikasi kaki diabetes pasien diabetes mellitus di Wilayah Kerja Puskesmas Banguntapan 3 Bantul.
\end{abstract}

Kata kunci : metode pendidik teman sebaya, pengetahuan, komplikasi kaki diabetes

\section{ABSTRACT}

Background: Diabetic foot is a common complication experienced by people with diabetes mellitus. Knowledge of the complications of diabetic foot is necessary to perform self-care properly. Objective: to analyze the effectiveness of peer educator method health education to increase knowledge of diabetes foot complications prevention. Methods: Quasi experimental with pre-post test control group design was used in this study. Peer educator intervention was used in this study on all patients with type 2 diabetes mellitus at Banguntapan 3 Community Health Center Bantul, as many as 30 patients. Sampling using total sampling, the respondents were divided into 2 (15 interventions and 15 controls). The research instrument was a questionnaire of knowledge about the prevention of diabetic foot complications given before and after the intervention, analyzed by using paired t-test. Results: the pretest in the control group was in the moderate category (73.3\%) and the intervention group (66.7\%). The posttest results of the control group were in the moderate category $(66.7 \%)$ and an increase in the intervention group (67.7\%). Results: Bivariate analysis showed that there was an influence between the control and experimental groups on knowledge of foot care in patients with diabetes using peer method health education with a p-value of 0.006. Conclusion: the peer educator method is proven to be effective in increasing knowledge of the prevention of diabetes foot complications in diabetes mellitus patients in the Banguntapan 3 Community Health Center, Bantul.

Keywords: Peer support, Knowledge, Diabetic foot complication 


\section{Latar Belakang}

Diabetes mellitus merupakan suatu penya kit menahun yang yang ditandai oleh kadar glukosa darah melebihi normal dan gangguan metabolisme karbohidrat, lemak dan protein yang disebabkan oleh kekurangan hormone insulin secara realtif maupun absolut (Hestiana, 2017). Pencegahan yang dapat dilakukan penederita diabetes mellitus yaitu dengan membuat perubahan gaya hidup pasien, seperti meningkatkan diet dan latihan fisik (Juwita and Febrina, 2018).

WHO menerangkan penderita diabetes mellitus mencapai 171,2 juta orang dan diperkirakan tahun 2030 akan mencapai 366,2 juta orang, angka ini diperkirakan naik hingga 114\% (Jayaningrum, 2016). Survey dari WHO menyebutkan pada tahun 2000 penderita diabetes mellitus di Indonesia sekitar 8,4 juta orang dan diprediksi akan meningkat menjadi 21,3 juta orang pada tahun 2030 (Adikusuma et $a l ., 2018)$. Jika kondisi pada penderita diabetes tersebut tidak terkendali dapat menyebabkan komplikasi akut maupun kronis. Salah satu komplikasi penderita diabetes mellitus adalah terjadi adalah diabetic foot (Iriani, Haryani and Aulawi, 2017).

Kaki diabetic di Indonesia merupakan permasalahan yang belum dapat terkelola dengan baik. Prevalensi kaki diabetic di Indonesia sebesar 15\% dan sering kali berakhir dengan kecacatan dan kematian (Purwanti and Maghfirah, 2016). Manifestasi yang nampak berupa adanya ulkus, infeksi dan gangren dan artropati Charcot (Purwanti and Maghfirah, 2016). Ulkus kaki diabetic merupkan luka yang dialami oleh penderita diabetes pada area kaki dengan kondisi luka mulai dari luka superficial, nekrosis kulit, sampai luka dengan ketebalan penuh yang dapat meluas kejaringan lain seperti tendon, tulang dan persendian. Jika ulkus dibiarkan tanpa ada penatalaksanaan yang baik maka akan mengakibatkan infeksi atau gangrene. Ada dua tindakan dalam prinsip dasar pengelolaan diabetic foot yaitu tindakan rehabilitasi dan tindakan pencegahan (Juwita and Febrina, 2018).

Tindakan rehabilitasi pada pengelolaan diabetic foot meliputi program terpadu yaitu evaluasi tukak, pengendalian kondisi metabolik, debridemen luka, biakan kuman, antibiotika tepat guna, tindakan bedah rehabilitatif dan rehabilitasi medik. Sedangkan tindakan pencegahan diabetic foot meliputi edukasi perawatan kaki, sepatu diabetes dan senam kaki (Handayani, 2018).

Diabetes mellitus merupakan penyakit kronis yang membutuhkan perawatan kompleks dan berkelanjutan. Terdapat 4 pilar penatalaksanaan penderita diabetes mellitus, yaitu pengobatan, latihan, diet, dan edukasi (Putra and Berawi, 2015). Kompleksitas dan keberlanjutan penanganan diabetes mellitus ini membutuhkan keterampilan pasien dalam mengintegrasikan penanganan diabetes mellitus secara mandiri dan berkelanjutan. Diabetes self management education (DSME) perlu diberikan pada pasien diabetes (Ridwan, Barri and Nizami, 2018).

Dukungan dari teman sebaya (peer support/peer group) merupakan suatu sistem 
yang memberi serta menerima bantuan dengan prinsip rasa hormat, tanggung jawab bersama, dan kesepakatan bersama tentang hal-hal yang membantu (Yin et al., 2015). Tindakan edukasi tentang perawatan diabetes mellitus dapat diberikan dari teman sebaya yang sedang menderita diabetes mellitus juga. Tindakan ini termasuk dalam tindakan preventif yang dapat dipelajari yang dapat meningkatkan pengetahuan dan keterampilan untuk melakukan perawatan diri setiap hari untuk menghindari komplikasi diabetik jangka panjang.

Keuntungan dari metode ini yaitu informasi yang disampaikan oleh pendidik sebaya kepada kelompoknya akan mendapat feedback secara langsung. Penggunaan bahasa yang kurang lebih sama dalam kelompok sebaya dapat mengurangi kesalahpahaman dalam penerimaan informasi. Seorang pendidik sebaya (peer educator) dapat berperan sebagai role model bagi kelompok sebayanya (Iriani, Haryani and Aulawi, 2017). Adanya hubungan interpersonal yang baik dalam kelompok sebaya akan memudahkan pendidik sebaya dalam mempengaruhi, mengubah serta meningkatkan perilaku kesehatan.

Hasil studi pendahuluan terhadap penderita diabetes mellitus di Puskesmas Banguntapan 3 didapatkan data 8 dari 15 penderita diabetes mellitus mengetahui bahwa penyakir diabetes mellitus dapat menimbulkan komplikasi pada kaki, mereka mengatakan belum pernah mendengar mengenai senam kaki untuk penderita diabetes mellitus, 10 dari 15 penderita diabetes mellitus belum pernah mendapatkan pendidikan kesehatan tentang manfaat senam kaki pada penderita diabetes mellitus sebagai upaya pencegahan komplikasi diabetes pada kaki (diabetic foot).

Berdasarkan uraian latar belakang, maka peneliti tertarik melakukan penelitian tentang efektivitas pendidikan kesehatan dengan metode pendidik teman sebaya terhadap peningkatan pengetahuan pencegahan komplikasi kaki diabetes (diabetic foot) Di Puskesmas Banguntapan 3 Bantul.

\section{Metode}

Jenis penelitian yang digunakan pada penelitian ini adalah pra eksperiment dengan rancangan one group pretest dan postest. Penelitian ini membandingkan antara nilai postest dan pretest. Penelitian ini dilaksanakan di wilayah kerja Puskesmas Banguntapan 3 Yogyakarta. Penelitian dilaksanakan pada bulan Desember 2017 - Februari 2018. Populasi dalam penelitian ini adalah semua klien diabetes mellitus tipe 2 yang berusia 40-60 tahun berdasarkan data kunjungan pasien bulan Januari - Oktober 2017 sebanyak 84 orang di wilayah kerja Puskesmas Banguntapan 3 Yogyakarta.

Penentuan sampel dalam penelitian ini menggunakan teknik purposive Sampling. Kriteria inklusi penelitian ini antara lain 1) klien DM tipe 2 yang bertempat tinggal di wilayah kerja Puskesmas Banguntapan 3 Yogyakarta, 2) usia 40-60 tahun, 3) mengikuti intervensi dari awal hingga akhir sesi untuk kelompok perlakuan, 4) bersedia menjadi responden penelitian.

Variabel dalam penelitian ini terdiri dari variabel bebas yaitu efektivitas pendidikan kesehatan dengan metode pendidik sebaya dan variabel terikat yaitu peningkatan pengetahuan 
pencegahan komplikasi kaki diabetes (diabetic foot). Instrumen yang digunakan dalam penelitian ini adalah kuesioner untuk memperoleh informasi tentang pengetahuan pasien tentang pencegahan kaki diabetik. Kuesioner yang digunakan adalah kuesioner baku atau terstandar. telah dilakukan uji validitas di Puskesmas Kotagede dengan responden untuk uji ini berjumlah 30 orang.

Uji validitas menggunakan pearson product moment (r) dan uji reliabilitas menggunakan alpha cronbach dan didapatkan nilai 0,739 sehingga lebih besar dari kriteria yang ditetapkan, yakni 0,70 $(0,739>0,70)$. Nilai reliabilitas yang relatif besar menunjukkan bahwa instrumen ini dapat dengan konsisten mengukur variabel pengetahuan dengan baik. Analisis data menggunakan analisis univariat dan bivariat. Analisis bivariate menggunakan uji paired t-test.

\section{Hasil}

\section{a. Distribusi Frekuensi Responden}

Tabel 1. Karakteristik Responden Berdasarkan Jenis Kelamin, Umur, Pekerjaan, Pendidikan, Lama Pekerjaan Di wilayah Kerja Puskesmas Banguntapan 3 Bantul

\begin{tabular}{|c|c|c|c|c|c|}
\hline \multirow{2}{*}{ No } & \multirow{2}{*}{ Karakteristik } & \multicolumn{2}{|c|}{ Kontrol } & \multicolumn{2}{|c|}{ Eksperimen } \\
\hline & & $(\mathrm{F})$ & $(\%)$ & (F) & $(\%)$ \\
\hline \multirow[t]{3}{*}{1} & Jenis kelamin & & & & \\
\hline & Laki-laki & 7 & 46,7 & 7 & 56,7 \\
\hline & Perempuan & 8 & 53.3 & 8 & 53.3 \\
\hline \multirow[t]{4}{*}{2} & Umur & & & & \\
\hline & $25-35$ th & 2 & 13.3 & 5 & 33.3 \\
\hline & $36-45$ th & 2 & 13.3 & 1 & 6.7 \\
\hline & $46-60$ th & 11 & 73.3 & 9 & 60.0 \\
\hline \multirow[t]{7}{*}{3} & Pekerjaan & & & & \\
\hline & PNS & 3 & 20.0 & 2 & 13.3 \\
\hline & Petani & 0 & 0 & 2 & 13.3 \\
\hline & Karyawan & 7 & 46.7 & 3 & 20.0 \\
\hline & swasta & & & & \\
\hline & Buruh & 4 & 26.7 & 6 & 40.0 \\
\hline & Tidak bekerja & 1 & 6.7 & 2 & 13.3 \\
\hline \multirow[t]{2}{*}{4} & Pendidikan & & & & \\
\hline & SD & 4 & 26.7 & 0 & 0 \\
\hline
\end{tabular}

\begin{tabular}{|c|c|c|c|c|c|}
\hline & SMP & 0 & 0 & 5 & 33.3 \\
\hline & SMA & 7 & 46.7 & 5 & 33.3 \\
\hline & Diploma & 3 & 20 & 5 & 33.3 \\
\hline & Tidak sekolah & 1 & 6.7 & 0 & 0 \\
\hline 5 & $\begin{array}{l}\text { Lama menderita DM } \\
<5 \text { th }\end{array}$ & 9 & 60.0 & 10 & 66.7 \\
\hline & $5-10$ th & 6 & 40.0 & 4 & 26.7 \\
\hline & $>10$ th & 0 & 0 & 1 & 6.7 \\
\hline & Total & 15 & 100 & 15 & 100 \\
\hline
\end{tabular}

Sumber: Data Primer

Pada tabel 1 menunjukkan data distribusi responden berdasarkan jenis kelamin baik pada kelompok kontrol dan kelompok eksperimen mayoritas jenis kelamin perempuan yaitu 53,3\% . Berdasarkan umur, menunjukkan bahwa sebagian besar responden yang berumur 46-60 tahun pada kelompok kontrol 73,3\% sedangkan kelompok eksperimen 60,0\%. Pekerjaan pada kelompok kontrol yang terbanyak adalah karyawan swasta sebanyak 46,7\% dan kelompok eksperimen dengan pekerjaan sebagai buruh sebanyak 40,0\%. Pendidikan, kelompok kontrol yang paling dominan 5 tingkat pendidikan SMA 46,7\% sedangkan kelompok eksperimen untuk tingkat pendidikan dari SMP, SMA, Diploma masingmasing jumlahnya sama 33,3\%. Lama menderita DM pada kelompok kontrol dan kelompok eksperimen yang terbanyak adalah lama menderita $<5$ tahun sebanyak 60,0\% kelompok kontrol dan kelompok eksperimen 66,7\%.

\section{b. Pengetahuan Perawatan Kaki Diabetik}

Tabel 2. Hasil Pretest dan Posttest Pengetahuan Perawatan Kaki Diabetik Di Wilayah Kerja Puskesmas Banguntapan 3 Bantul

\begin{tabular}{ccccccccc}
\hline \multirow{2}{*}{$\begin{array}{c}\text { Pengetahu } \\
\text { an }\end{array}$} & \multicolumn{4}{c}{ Pretest } & \multicolumn{5}{c}{ Postest } \\
\cline { 2 - 9 } & \multicolumn{3}{c}{ Kontrol } & \multicolumn{2}{c}{ Eksp } & \multicolumn{1}{c}{ Kontrol } & \multicolumn{2}{c}{ Eksp } \\
\cline { 2 - 9 } & $\mathrm{F}$ & $\%$ & $\mathrm{~F}$ & $\%$ & $\mathrm{~F}$ & $\%$ & $\mathrm{~F}$ & $\%$ \\
\hline Baik & 1 & 6.7 & 1 & 6.7 & 4 & 26. & 1 & 67. \\
& & & & & & 7 & 0 & 7 \\
Cukup & 1 & 73. & 1 & 67. & 1 & 66. & 5 & 33 \\
& 1 & 3 & 0 & 7 & 0 & 7 & & \\
Kurang & 3 & 20 & 4 & 26. & 1 & 6.7 & 0 & 0 \\
& & & & 7 & & & & \\
\hline Total & 1 & 100 & 1 & 100 & 1 & 100 & 1 & 100 \\
& 5 & & 5 & & 5 & & 5 & \\
\hline
\end{tabular}

Sumber : Data primer hasil uji SPSS 
Tabel 2 diperoleh hasil pretest pengetahuan perawatan kaki pada kelompok kontrol maupun eksperimen rata-rata dalam kategori cukup yaitu $73,3 \%$ pada kelompok kontrol dan 66,7\% pada kelompok eksperimen. Hasil posttest pengetahuan responden pada kelompok kontrol maupun kelompok eksperimen mengalami peningkatan pada kategori baik yaitu 26,7\% pada kelompok kontrol dan 67,7 pada kelompok eksperimen.

Tabel 3.Analisis Perbedaan dan Uji Pengaruh Pengetahuan Perawatan Kaki Pretest dan Posttest Pada Kelompok Kontrol dan Intervensi Di wilayah Kerja Puskesmas Banguntapan 3 Bantul

\begin{tabular}{lcclll}
\hline Kontrol & $\mathrm{N}$ & Mean & $\begin{array}{l}\text { ST } \\
\text { deviation }\end{array}$ & $\mathrm{T}$ & p-value \\
\hline Pretest & 15 & 18,20 & 3,189 & $-9,865$ & 0,001 \\
Posttest & 15 & 21,07 & 2,939 & & \\
\hline Intervensi & & & & $-34,293$ & 0,016 \\
\hline Pretest & 15 & 18,47 & 2,558 & & \\
Posttest & 15 & 24,07 & 2,520 & & \\
\hline Uji Pengaruh & & & & $-3,001$ & 0,006 \\
\hline Kontrol & 15 & 21,07 & 2,939 & & \\
Eksperimen & 15 & 24,07 & 2,520 & &
\end{tabular}

Sumber : Data primer hasil uji SPSS

Berdasarkan hasil uji statistik Paired t-Test pada tabel 3 menunjukkan adanya perbedaan rerata skor pengetahuan perawatan kaki yang signifikan sebelum dan setelah diberikan pendidikan kesehatan pada kelompok kontrol dengan nilai $\mathrm{p}$-value $=0,001$.

Berdasarkan hasil uji statistic Paired t-Test pada tabel 3 menunjukkan adanya perbedaan rerata skor pengetahuan perawatan kaki karena nilai $\mathrm{p}$-value $=0$, 016.

Berdasarkan hasil paired t-Test pada tabel 3 dapat terlihat bahwa ada perbedaan rerata skor pengetahuan perawatan kaki yang signifikan antara kelompok kontrol dan eksperimen dengan nilai p-value 0,006 yang berarti Ho ditolak.

\section{Pembahasan}

\section{a. Perbedaan Pengetahuan Perawatan Kaki Sebelum dan Setelah Pendidikan Kesehatan Pada Kelompok Kontrol}

Hasil penelitian ini menunjukkan bahwa sebelum diberikan pendidikan kesehatan diperoleh nilai rerata 18,20 setelah diberikan pendidikan kesehatan diperoleh nilai rerata 21,07, maka terjadi kenaikan rereta pengetahuan perawatan kaki sebesar 2,87, sedangkan hasil uji beda Paired t-Test diperoleh $\mathrm{p}$-value $=0,001$. Hal ini menunjukkan bahwa terdapat perbedaan pengetahuan perawatan kaki sebelum dan sesudah diberikan pendidikan kesehatan pada kelompok kontrol. Pengetahuan merupakan hasil tahu dan ini terjadi setelah orang melakukan penginderaan terhadap suatu objek tertentu. Pengetahuan terjadi melalui panca indra manusia, yakni: indra penglihatan, pendengaran, penciuman, rasa, dan raba. Sebagian besar pengetahuan diperoleh melalui mata dan telinga (Mulyawati, Kuswardinah and Yuniastuti, 2017).

Hasil penelitian ini didukung oleh Diani yang menyebutkan terjadi peningkatan tingkat pengetahuan dalam melakukan perawatan kaki dan pencegahan terjadinya komplikasi diabetes mellitus (Diani, Waluyo and Sukmarini, 2013). Perubahan rata-rata pada tingkat pengetahuan pada kelompok kontrol 
disebabkan oleh faktor konsentrasi yang terpecah pada saat melakukan pengisian kuesioner pretest yang dikarenakan sedang menunggu pemeriksaan gula darah dan pengisian kuesioner pemeriksaan posttest dilakukan setelah pemeriksaan gula darah dan menunggu dokter.

\section{b. Perbedaan Pengetahuan Perawatan}

Kaki Sebelum dan Setelah Pendidikan Kesehatan Pada Kelompok Eksperimen

Hasil penelitian ini menunjukkan bahwa sebelum diberikan pendidikan kesehatan diperoleh nilai rerata 18,47 setelah diberikan pendidikan kesehatan diperoleh nilai rerata 24,07 , maka terjadi kenaikan rerta pengetahuan perawatan kaki sebesar 5,60, sedangkan hasil uji beda Paired t-Test diperoleh p-value $=0,016$. Hal ini menunjukkan bahwa terdapat perbedaan pengetahuan perawatan kaki sebelum dan sesudah diberikan pendidikan kesehatan pada kelompok eksperimen. Pendidikan kesehatan selama ini belum maksimal sehingga perlu dukungan semua pihak dan advokasi. Pendidikan kesehatan pada pasien kaki diabetik diharapkan lebih ditekankan agar mereka lebih mengetahui tentang definisi, tanda dan gejala, perawatan kaki diabetik, serta pencegahan kaki diabetik. Hal ini relevan dengan pendapat Notoatmodjo yang menyatakan pada dasarnya tujuan utama pendidikan kesehatan adalah untuk mencapai 3 hal, yaitu: (1) peningkatan pengetahuan atau sikap masyarakat; (2) peningkatan perilaku masyarakat; (3) peningkatan status kesehatan masyarakat (Ridwan, Barri and Nizami, 2018).

Hasil penelitian ini didukung oleh menunjukkan tingkat pengetahuan dalam melakukan perawatan kaki yang baik dapat menjadi intervensi pencegahan tejadinya komplikasi diabetes mellitus. Perubahan rata-rata pada tingkat pengetahuan pada kelompok eksperimen disebabkan oleh faktor diberikannya pendidikan kesehatan melalui teman sebaya.

Peningkatan pengetahuan pada kelompok eksperimen terjadi karena diberikan pendidikan kesehatan melalui audiovisual dengan LCD, maka banyak responden yang lebih tertarik dan memperhatikan visualisasi maupun gambaran cara perawatan kaki dan pencegahan terjadinya komplikasi diabetestes mellitus, sehingga ingatan lebih kuat, lebih mudah dipahami dan menimbulkan kesan yang baik.

c. Pengaruh Pendidikan Kesehatan tentang Perawatan Kaki Diabetik Terhadap Pengetahuan Perawatan Kaki Pada Diabetes Melitus di Puskesmas Banguntapan 3 Bantul

Hasil penelitian menunjukkan bahwa ada pengaruh pendidikan kesehatan tentang perawatan kaki diabetik terhadap pengetahuan perawatan kaki pada penderita diabetes mellitus di Puskesmas Banguntapan 3 Bantul. Hal ini dilihat dari nilai rerata pada kelompok eksperimen sebesar 24,07 sedangkan pada nilai rerata pada kelompok kontrol sebesar 21,07, sehingga terdapat selisih sebesar 3,00, dan 
hasil uji beda Independent t-Test diperoleh nilai p-value sebesar 0,006 .

Penelitian ini juga didukung oleh Nurmawati pendidikan kesehatan tentang perawatan kaki bagi penderita diabetes mellitus dipilih karena sebagai bantuan untuk masalah kehidupan dampak lanjutan dari penyakit diabetes mellitus dengan cara yang tepat (Nurmawati, Sari and Setyaningsih, 2018). Pemberian pendidikan kesehatan diharapkan dapat mengubah perilaku penderita diabetes mellitus dalam upaya mencegah komplikasi diabetes mellitus. Pramesti juga mengungkapkan bahwa penelitiannya ini didukung oleh beberapa faktor diantaranya faktor kesiapan penyuluh atau penyaji yang telah mempersiapkan materi yang akan disampaikan dan menguasai materi yang akan dijelaskan. Pendidikan kesehatan didefinisikan sebagai usaha atau kegiatan untuk membantu individu, kelompok atau masyarakat dalam meningkatkan kemampuan atau perilaku untuk mencapai kesehatan secara optimal (Ratnasari, 2019).

Hasil ini menunjukkan bahwa kelompok yang mendapatkan pendidikan kesehatan lebih mengerti dalam melakukan perawatan kaki dibanding kelompok yang tidak mendapatkan pendidikan kesehatan. Hal ini membuktikan bahwa melalui pendidikan kesehatan, terjadi perubahan perilaku responden dalam merawat kaki. Efektivitas pengaruh pendidikan kesehatan dengan menggunakan media audiovisual dibandingkan leaflet, disebabkan karena dengan audiovisual memiliki keuntungan seperti meningkatkan pengertian yang lebih baik, membuat ingatan terhadap pelajaran lebih lama, membantu memberikan konsep pertama atau kesan yang benar, sehingga penggunaan pendidikan kesehatan melalui media audiovisual lebih baik daripada media leaflet

\section{Kesimpulan}

Pendidikan kesehatan pada penderita diabetes mellitus dapat diberikan menggunakan metode pendidik teman sebaya. Hasil pretest pengetahuan perawatan kaki pada kelompok control mayoritas dalam kategori cukup yaitu $73,3 \%$, sedangkan kategori cukup atau $66,7 \%$ pada kelompok eksperimen. Hasil postest pengetahuan pada kelompok control mayoritas masih berada pada kategori cukup yaiti $66,7 \%$ dan menunjukkan adanya peningkatan pada kelompok eksperimen dimana mayoritas responden dalam kategri pengetahuan yang baik sebanyak 67,7\%. Hasil analisa bivariate menunjukkan adanya pengaruh yang signifikan antara kelompok kontrol dan eksperimen terhadap pengetahuan perawatan kaki pada penderita dibetes dengan menggunakan pendidikan kesehatan melalui metode teman sebaya dengan nilai $\mathrm{p}$-value 0,006 . 


\section{Ucapan Terima Kasih}

Dalam hal ini penulis mengucapkan terima kasih kepada STIKES Surya Global Yogyakarta yang telah memberikan dukungan moril maupun materiil dalam penyelesaian publikasi ini.

\section{Daftar Pustaka}

Adikusuma, W. et al. (2018) 'Evaluasi Kualitas Hidup Pasien Diabetes Melitus Tipe 2 Rumah Sakit Umum Evaluasi Kualitas Hidup Pasien Diabetes Melitus Tipe 2 Rumah Sakit Umum PKU Muhammadiyah Bantul'.

Diani, N., Waluyo, A. and Sukmarini, L. (2013) 'Pengetahuan Klien Tentang Diabetes Mellitus Tipe 2 Berpengaruh Terhadap Kemampuan Klien Merawat Kaki', Jurnal Keperawatan Indonesia, 16(2), pp. 120127.

Handayani, T. (2018) 'Pelatihan Senam Kaki Bagi Dokter Di Kabupaten Cianjur Dalam Pencegahan Komplikasi Diabetic Foot', Abdimas Dewantara, 1(1), pp. 57-64.

Hestiana, D. W. (2017) 'Faktor-Faktor Yang Berhubungan Dengan Kepatuhan Dalam Pengelolaan Diet Pada Pasien Rawat Jalan DIabetes Mellitus Tipe 2 Di Kota Semarang', Jurnal of Health Education, 2(2), pp. 138-145.

Iriani, T. T., Haryani and Aulawi, K. (2017) 'Efektivitas Peer Group Diabetes Self Care Education Terhadap Diabetes Self Care Activities Pasien DM', JPPNI, 2(1).

Jayaningrum, F. (2016) 'Efektivitas Media Smart Book Dalam Meningkatkan Pengetahuan Tentang Penatalaksanaan Diabetes Mellitus Pada Pasien Diabetes Mellitus Di Puskesmas Kedungmundu Kota Semarang', Journal of Health Education, 1(2).

Juwita, L. and Febrina, W. (2018) 'Model Pengendalian Kadar Gula Darah Penderita Diabetes Mellitus', Jurnal Endurance, 3(1), pp. 102-111.
Mulyawati, I., Kuswardinah, A. and Yuniastuti, A. (2017) 'Pengaruh Pendidikan Kesehatan tentang Keamanan Jajanan terhadap Pengetahuan dan Sikap Anak', Public Health Perspective Journal, 2(1), pp. 1-8.

Nurmawati, T., Sari, Y. K. and Setyaningsih, M. (2018) 'Efektifitas Pendidikan Kesehatan dengan Metode Ekspositori tentang Meal Planning terhadap Pola Makan Pasien DM Tipe 2', Jurnal Ners Dan Kebidanan, 5(3), pp. 257-262. doi: 10.26699/jnk.v5i3.ART.p257.

Purwanti, L. E. and Maghfirah, S. (2016) 'Faktor Risiko Komplikasi Kronis (Kaki Diabetik) Dalam Diabetes Mellitus Tipe 2', The Indonesian Journal of Health Science, 7(1), pp. 26-39.

Putra, I. W. A. and Berawi, K. N. (2015) 'Empat Pilar Penatalaksanaan Pasien Diabetes Mellitus Tipe 2 Four Pillars of Management of Type 2 Diabetes Mellitus Patients', 4(Dm), pp. 8-12.

Ratnasari, N. Y. (2019) 'Upaya Pemberian Penyuluhan Kesehatan tentang Diabetes Mellitus dan Senam Kaki Diabetik terhadap Pengetahuan dan Keterampilan Masyarakat Desa Kedungringin, Wonogiri', Indonesian Journal of Coummunity Services, 1(1), pp. 105-115.

Ridwan, A., Barri, P. and Nizami, N. H. (2018) 'Efektivitas Diabetes Self Management Education Melalui SMS Terhadap Pengetahuan Penderita Diabetes Mellitus : A Pilot Study', IX(1), pp. 65-71.

Yin, J. et al. (2015) 'Effects of Providing Peer Support on Diabetes Manage- ment in People With Type 2 Diabetes', pp. 42-49. doi: 10.1370/afm.1853.Hong. 